Jurnal Kesehatan Islam

Publikasi oleh Fakultas Kedokteran, Universitas Islam Malang

Email: jkesislam@unisma.ac.id

Home Page : http://riset.unisma.ac.id/index.php/jki

\title{
HUBUNGAN ANTARA PRESTASI BELAJAR DENGAN KEIKUTSERTAAN DAN TINGKAT KEAKTIFAN DALAM BERORGANISASI MAHASISWATAHUN KEDUA DAN KETIGA FAKULTAS KEDOKTERAN UNIVERSITAS ISLAM MALANG
}

\author{
Rizki Anisa \\ Medical Education Unit Fakultas Kedokteran Universitas Islam Malang \\ ABSTRAK
}

Latar Belakang: Kompetensi pada bidang pendidikan kedokteran telah ditetapkan dalam SKDI. Kegiatannon formal(ekstrakurikuler)dapat dipergunakan sebagai salah satu penunjang mencapai kompetensi misalnya dengan mengikuti organisasi. Namun seringkali hal ini dianggap mempengaruhi prestasi belajar.Penelitian ini bertujuan untukmengetahui hubungan antara prestasi belajar dengan keikutsertaan dan keaktifan dalam berorganisasi pada mahasiswa tahun kedua dan ketiga FK UNISMA.

Metode: Penelitian ini merupakan penelitian kuantitatif dengan rancangan deskriptif analitikdengan pendekatan cross sectionaldan menggunakan uji statistik non parametrik. Pengambilan data dengan menggunakan kuisioner keaktifan berorganisasi.

Hasil: Responden sebanyak 102 mahasiswa tingkat dua dan tiga FK UNISMA. 30 responden tidak mengikuti organisasi dan 72 mengikuti organisasi. Hasil analisis data hubungan antara prestasi belajar dan keikutsertaan berorganisasi didapatkan nilai signifikansi 0.039 ( $p<0.05)$. Sedangkan hasil analisis data hubungan antara prestasi belajar dan tingkat keaktifan berorganisasi didapatkan nilai signifikansi $0.110(p<0.05)$.

Kesimpulan: Jadi dapat disimpulkan bahwa terdapat hubungan antara prestasi belajar dengan keikutsertaan mahasiswa dalam organisasi namun tidak terdapat hubungan antara prestasi belajar dengan tingkat keaktifan mahasiswa dalam berorganisasi.

Kata kunci : prestasi belajar, keaktifan organisasi

\section{RELATIONSHIP BETWEEN LEARNING ACHIEVEMENTS WITH PARTICIPATION AND LEVEL OF STUDENT ACTIVITY IN ORGANIZATION IN SECOND AND THIRD YEAR STUDENTS OF FACULTY OF MEDICINE ISLAMIC UNIVERSITY OF MALANG}

\author{
Rizki Anisa \\ Medical Education Unit Faculty of Medicine, Islamic University of Malang \\ ABSTRACT
}

Background : Competence in the field of medical education has been established in SKDI. Non-formal activities (extracurricular) can be used as one of the supporters to achieve competence for example by following the organization. But often this is considered to affect learning achievement. This study aims to determine the relationship between learning achievement with participation and level of student activity in organization in second and third year students of Faculty Of Medicine Islamic University Of Malang. Method : This research is a quantitative research with descriptive analytic design with cross sectional approach and using non parametric statistic test. We used organization activity questionnaire to measure the level of activity in organization. Results : Respondents were 102 students of second and third grade of FK UNISMA. 30 respondents did not follow the organization and 72 followed the organization. The result of data analysis of the relationship between learning achievement and organizational participation was found significance value $0.039(p<0.05)$. While the result of data analysis of the relationship between learning achievement and organizational activity level obtained significance value $0.110(p<0.05)$. Conclusion : It can be concluded that there is a relationship between learning achievement with the participation of students in the organization but there is no relationship between learning achievement with the level of student activity in the organization.

Keywords : Student achievement, level of student activity, organization 


\section{Latar Belakang}

Kompetensi pada bidang pendidikan kedokteran telah ditetapkan dalam Standar Kompetensi Dokter Indonesia (SKDI). Pada SKDI

terdapat tujuh area kompetensi yaitu profesionalitas yang luhur, mawas diri dan pengembangan diri, komunikasi efektif, pengelolaan informasi, landasan ilmiah ilmu kedokteran, keterampilaan klinis dan pengelolaan masalah kesehatan. ${ }^{1}$

Beberapa cara dilakukan untuk mencapai kompetensi tersebut. Selain Pendidikan formal di dalam kampus yang tercakup dalam kurikulum, juga ditempuh melalui jalur non formal (ekstrakurikuler) sebagai sarana penunjang untuk mencapai kompetensi misalnya dengan mengikuti organisasi baik di dalam maupun di luar kampus. Dengan mengikuti suatu organisasi, mahasiswa dapat memperoleh pengalaman berinteraksi dan bekerjasama serta berkomunikasi dengan teman sejawat maupun dari berbagai profesi yang lain. Kemampuan

tersebut sesuai dengan kompetensi profesionalitas yang luhur, pengelolaan masalah kesehatan dan komunikasi efektif. ${ }^{1}$

Pada saat mengikuti organisasi, mahasiswa juga mendapatkan pengalaman dan berlatih melakukan manajemen dalam organisasi. Hal ini sesuai dengan kompetensi pengelolaan masalah kesehatan. Pada kompetensi ini, seorang lulusan dokter dituntut untuk mampu mengelola sumber daya manusia, keuangan, sarana dan prasarana secara efektif dan efisien. Kemampuan ini wajib dimiliki oleh seorang lulusan dokter karena jika mereka lulus nanti, mereka mampu mengelola manajemen puskesmas, klinik dokter keluarga maupun rumah sakit. Selain itu, mahasiswa yang menjadi aktif berorganisasi dapat belajar menjadi seorang communicator, decision maker, community leader dan manager. Hal ini sesuai dengan profil dokter masa depan yang ditentukan oleh $\mathrm{WHO}^{2}$

Manfaat yang didapatkan oleh mahasiswa pada saat mengikuti organisasi banyak sekali. Namun seringkali keaktifan mahasiswa dalam mengikuti organisasi dianggap sebagai salah satu hal yang mempengaruhi prestasi belajar. Mahasiswa yang aktif dalam berorganisasi diduga mempunyai prestasi belajar yang kurang baik bila dibandingkan dengan mahasiswa yang tidak mengikuti organisasi.

Beberapa penelitian tentang hubungan antara keaktifan mahasiswa dalam berorganisasi dengan prestasi belajar sudah banyak dilakukan. Febriana,dkk (2013), meneliti hubungan antara keaktifan berorganisasi dengan prestasi belajar mahasiswa Fakultas IImu Keperawatan Universitas Indonesia. ${ }^{3}$ Pratiwi (2016), meneliti pengaruh keaktifan mahasiswa dalam organisasi dan motivasi belajar terhadap prestasi belajar mahasiswa Fakultas Ekonomi Universitas Negeri Yogyakarta. ${ }^{4}$ Nanda (2017), meneliti hubungan kebiasaan belajar dan keaktifan berorganisasi terhadap prestasi belajar mahasiswa tahun ketiga Fakultas Kedokteran Universitas Lampung. ${ }^{5}$ Berdasarkan paparan tersebut, peneliti ingin melakukan penelitian untuk mengetahui hubungan antara prestasi belajar dengan keikutsertaan dan tingkat keaktifan dalam berorganisasi pada mahasiswa tahun kedua dan ketiga Fakultas Kedokteran Universitas Islam Malang (FK UNISMA).

\section{Metode}

Penelitian ini merupakan penelitian kuantitatif dengan rancangan deskriptif analitik dengan pendekatan cross sectional dengan menggunakan uji statistik non parametrik. Pengambilan data tentang tingkat keaktifan dalam berorganisasi dilakukan pada satu waktu dengan menggunakan kuisioner.

Penelitian dilakukan di FK UNISMA pada tanggal 1-7 Maret 2018.Subjek pada penelitian ini adalah semua populasi mahasiswa angkatan 2015 dan 2016 FK UNISMA. Kedua angkatan tersebut dipilih oleh peneliti karena mereka pada saat ini sedang menjabat sebagai pimpinan maupun pengurus organisasi kemahasiswaan di FK UNISMA.

Instrumen penelitian yang dipergunakan dalam penelitian ini adalah kuisioner tentang keaktifan berorganisasi yang disusun oleh Pratiwi. ${ }^{4}$ Kuisioner ini terdiri dari13 pertanyaan untuk mengetahui tentang komitmen, tanggung 
jawab, keadaptasian dan ambisi untuk maju. Pada kuisoner ini terdapat pernyataan positif dan negatif. Pada pernyataan positif, pilihan jawaban terdiri dari sangat setuju, setuju, netral, kurang setuju dan tidak setuju yang dikonversikan menjadi nilai 5,4,3,2 dan 1. Pada pernyataan negatif pilihan jawabannya sama namun angka konversinya dibalik menjadi 1,2,3,4 dan 5 .

Kuisioner ini divalidasi lagi oleh peneliti dengan responden mahasiswa angkatan 2014 berjumlah 30 orang. Berdasarkan hasil uji validitas, terdapat 2 pernyataan yang tidak valid sehingga pernyataan dalam kuisioner tersebut menjadi 11 butir.

Prosedur dalam penelitian ini yaitu responden mengisi kuisioner dalam google form dan boleh diisi dalam rentang waktu 1 minggu. Responden mengisi biodata termasuk data tentang Indeks Prestasi Kumulatif (IPK) terakhir, data tentang ikut organisasi atau tidak, jenis organisasi yang diikuti, alasan keikutsertaan dalam organisasi dilanjutkan dengan mengisi kuisioner keaktifan dalam berorganisasi. Prestasi belajar dalam penelitian ini diukur dengan menggunakan IPK.

\section{Hasil}

Sebanyak 102 mahasiswa mengisi kuisioner tentang keaktifan berorganisasi yang terdiri dari 11 butir pertanyaan.49 orang (48.04\%) berasal dari angkatan 2015 dan 53 orang (51.96) berasal dari angkatan 2016 (tabel 1).

Tabel 1. Distribusi responden berdasarkan angkatan

\begin{tabular}{lll}
\hline Angkatan & Jumlah & Persentase \\
\hline 2015 & 49 & 48.04 \\
2016 & 53 & 51.96 \\
\hline Total & 102 & 100 \\
\hline
\end{tabular}

Berdasarkan keikutsertaan dalam organisasi, 72 orang $(70.58 \%)$ merupakan mahasiswa yang ikut dalam berorganisasi sedangkan 30 orang (29.42\%) tidak ikut (tabel 2).
Tabel 2. Karakteristik responden berdasarkan keikutsertaan dalam organisasi

\begin{tabular}{lll}
\hline Keikutsertaan & Jumlah & \\
Organisasi & responden & Persentase (\%) \\
\hline Ikut & 72 & 70.58 \\
Tidak ikut & 30 & 29.42 \\
\hline Total & 102 & 100 \\
\hline
\end{tabular}

Berdasarkan hasil kuisioner tentang keaktifan berorganisasi, didapatkan nilai mean sebesar 37.83, median sebesar 39, modus sebesar 40, standar deviasi sebesar 7.37, nilai maksimum sebesar 53 dan nilai minimum sebesar 11. Kemudian dilakukan kategorisasi tingkat keaktifan berorganisasi menggunakan rumus di bawah ini: ${ }^{6}$

Nilai minimal $>\mathrm{X} \geq \mathrm{M}-1,5 \mathrm{SD}>\quad$ Sangat Rendah

$\mathrm{M}>\mathrm{X} \geq \mathrm{M}-1,5 \mathrm{SD}=$ Rendah

$M+1,5 S D>X \geq M=$ Tinggi

$M+1,5 S D>X \geq$ nilai maksimal = Sangat Tinggi Sehingga didapatkan hasil kategori sangat rendah antara nilai 11-26, rendah antara 27-36, tinggi antara 37-48 dan sangat tinggi antara 49-53. Pada gambar 1 tampak bahwa sebagian besar responden tergolong memiliki tingkat keaktifan tinggi dalam berorganisasi yaitu sebanyak 51 orang $(70.83 \%) .14$ orang ( $19.45 \%)$ tergolong dalam kategori rendah, 6 orang $(8.33 \%)$ kategori sangat tinggi dan 1 orang (1.39\%) tergolong sangat rendah.

\section{Gambar 1. Kategorisasi tingkat keaktifan responden dalam berorganisasi}

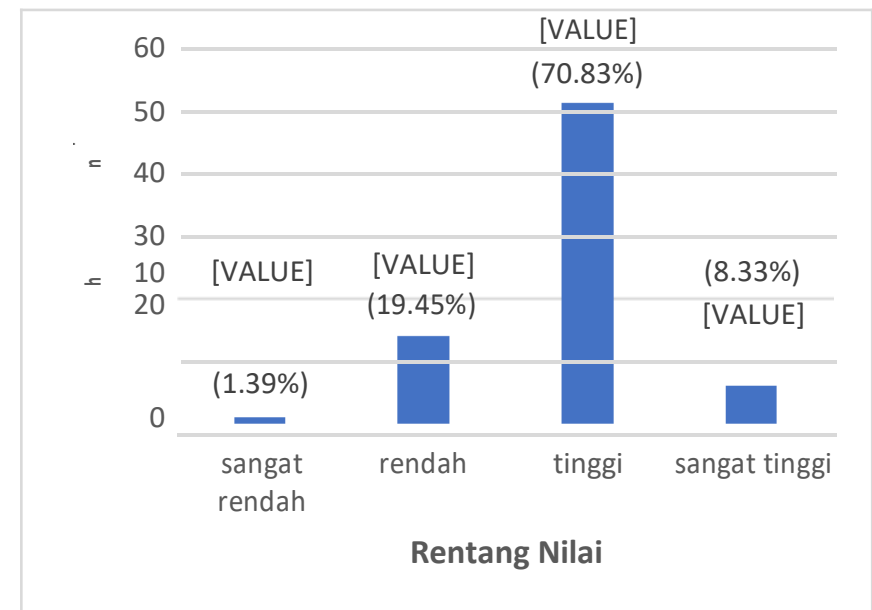


Pada tabel 3, menggambarkan organisasi yang diikuti oleh para responden. Sebagian besar responden mengikuti organisasi tingkat fakultas yaitu sebanyak 54 orang (75\%). 12 orang responden (16.66\%) mengikuti organisasi di tingkat fakultas dan luar kampus. 4 orang responden (5.56\%) hanya mengikuti kegiatan di luar kampus. Sebanyak masing-masing 1 orang responden (1.39\%) mengikuti kegiatan di tingkat universitas dan tingkat universitas serta luar kampus.

Tabel 3. Distribusi responden berdasarkan organisasi yang diikuti

\begin{tabular}{lll}
\hline Organisasi yang diikuti & $\begin{array}{l}\text { Jumlah } \\
\text { responden }\end{array}$ & $\begin{array}{l}\text { Persentase } \\
\text { (\%) }\end{array}$ \\
\hline $\begin{array}{l}\text { Tingkat fakultas } \\
\text { Tingkat universitas }\end{array}$ & 1 & 75 \\
$\begin{array}{l}\text { Luar kampus } \\
\text { Tingkat fakultas }\end{array}$ & 4 & 1.39 \\
universitas & 1 & 5.56 \\
$\begin{array}{l}\text { Tingkat fakultas \& } \\
\text { kampus }\end{array}$ & 12 & 1.39 \\
\hline Total & 72 & 16.66 \\
\hline
\end{tabular}

Sebagian besar responden, 66 orang (29.2\%) mengikuti organisasi karena ingin mencari pengalaman. 53 orang responden (23.45\%) mengikuti organisasi karena ingin melatih ketrampilan sedangkan 43 orang (19.03\%) ingin menambah teman. 29 orang responden (12.83\%) mengikuti organisasi karena ingin mengoptimalisasi masa studi, 18 orang (7.97\%) ingin mengembangkan hobi dan 16 orang (7.08\%) ingin mengisi waktu. Hanya 1 orang responden $(0.44 \%)$ yang beralasan mengikuti organisasi karena ikut-ikutan teman saja (tabel 4).

Tabel 4. Distribusi responden berdasarkan alasan ikut organisasi

\begin{tabular}{lll}
\hline Alasan ikut organisasi & $\begin{array}{l}\text { Jumlah } \\
\text { responden }\end{array}$ & $\begin{array}{l}\text { Persentase } \\
(\%)\end{array}$ \\
\hline Mencari pengalaman & 66 & 29.2 \\
Menambah teman & 43 & 19.03
\end{tabular}

\begin{tabular}{lcl} 
Mengisi waktu & 16 & 7.08 \\
Melatih ketrampilan & 53 & 23.45 \\
Mengembangkan hobi & 18 & 7.97 \\
Optimalisasi masa studi & 29 & 12.83 \\
Hanya ikut-ikutan teman & 1 & 0.44 \\
\hline
\end{tabular}

Pada tabel 5, tampak perbandingan IPK responden berdasarkan keikutsertaan dalam organisasi. Penggolongan IPK berdasarkan pada buku pedoman akademik mahasiswa FK UNISMA. IPK antara 2.00-2.74 mendapat predikat memuaskan, 2.75-3.24 mendapat predikat sangat memuaskan dan > 3.25 mendapat predikat dengan pujian (cum laude).

Responden yang mengikuti organisasi dengan IPK $\leq 2$ sebanyak 2 orang (1.96\%), lebih banyak bila dibandingkan dengan yang tidak mengikuti organisasi yaitu sebanyak 1 orang (0.98\%). Sebanyak 37 orang responden (36.28\%) yang mengikuti organisasi mempunyai IPK 2.02.74 , lebih banyak bila dibandingkan dengan yang tidak mengikuti organisasi yaitu sebanyak 22 orang $(21.57 \%)$. Sebanyak 32 orang responden (31.37\%) yang mengikuti organisasi mempunyai IPK antara 2.75-3.24, lebih banyak bila dibandingkan dengan yang tidak mengikuti organisasi yaitu 7 orang (6.86\%). Responden yang mengikuti organisasi dengan IPK $\geq 3.25$ sebanyak 1 orang $(0.98 \%)$ dan tidak ada yang memiliki IPK tersebut pada responden yang tidak mengikuti organisasi.

Berdasarkan hasil analisis data menggunakan uji non parametrik (Mann Whitney) didapatkan nilai signifikansi 0.039 ( $p<$ 0.05). Jadi dapat disimpulkan bahwa terdapat hubungan antara prestasi belajar dengan keikutsertaan mahasiswa dalam organisasi. 
Tabel 5. Perbandingan IPK berdasarkan keikutsertaan dalam organisasi

\begin{tabular}{llllll}
\hline Organisasi & \multicolumn{5}{c}{ IPK } \\
Ikut/ & \multicolumn{3}{c}{ Nilai } \\
tidak & $<2$ & 2.74 & $2.74-3.24$ & $\geq 3.25$ & \\
& & & & & \\
Ikut & 2 & 37 & 32 & 1 & \\
& $(1.96 \%)$ & $(36.28 \%)$ & $(31.37 \%)$ & $(0.98 \%)$ & 0.05 \\
Tidak & 1 & 22 & 7 & & \\
ikut & $(0.98 \%)$ & $(21.57 \%)$ & $(6.86 \%)$ & &
\end{tabular}

Pada tabel 6. tampak perbandingan IPK berdasarkan tingkat keaktifan dalam berorganisasi. Responden dengan kategori keaktifan sangat rendah hanya 1 orang (1.39\%) yang mendapatkan IPK 2.0-2.74. Responden dengan kategori keaktifan rendah yang mempunyai IPK $<2$ hanya 1 orang (1.39\%), 10 orang (13.89\%) memiliki IPK antara 2.0-2.74 dan 3 orang (4.16\%) memiliki IPK antara 2.74-3.24). Responden dengan kategori keaktifan tinggi yang mempunyai IPK $<2$ hanya 1 orang (1.39\%), 24 orang (33.33\%) memiliki IPK antara 2.0-2.74, 25 orang (34.72\%) memiliki IPK antara 2.74-3.24) dan 1 orang (1.39\%) memiliki IPK $\geq 3.25$. Responden dengan kategori keaktifan sangat tinggi, 2 orang (2.78\%) memiliki IPK antara 2.02.74 dan 4 orang $(5.56 \%)$ memiliki IPK antara 2.74-3.24.

Berdasarkan hasil analisis data menggunakan uji non parametrik (Kruskall Wallis) didapatkan nilai signifikansi $0.110(p<0.05)$. Jadi dapat disimpulkan bahwa tidak terdapat hubungan antara prestasi belajar mahasiswadengan tingkat keaktifan dalam mengikuti organisasi.
Tabel 6. Perbandingan IPK berdasarkan tingkat keaktifan dalam organisasi

\begin{tabular}{llllll}
\hline Organisasi & IPK & & & & Nilai \\
& $<2$ & $2.0-$ & $2.74-$ & $p$ \\
Kategori & & 2.74 & 3.24 & $\geq 3.25$ & \\
sangat & & 1 & & & \\
rendah & & $(1.39 \%)$ & & & \\
& 1 & 10 & 3 & & \\
rendah & $(1.39 \%)$ & $(13.89 \%)$ & $(4.16 \%)$ & & 0.05 \\
& 1 & 24 & 25 & 1 & \\
tinggi & $(1.39 \%)$ & $(33.33 \%)$ & $(34.72 \%)$ & $(1.39 \%)$ & \\
sangat & & 2 & 4 & & \\
tinggi & & $(2.78 \%)$ & $(5.56 \%)$ & &
\end{tabular}

\section{Diskusi}

Pada penelitian ini didapatkan data bahwa sebagian sebagian besar responden mengikuti organisasi baik di dalam maupun di luar kampus. Namun sebagian besar mengikuti organisasi di tingkat fakultas. Selain itu, sebagian besar responden tergolong sebagai mahasiswa yang tingkat keaktifannya tinggi dalam berorganisasi. Berdasarkan alasan mengikuti organisasi, sebagian besar responden mengikuti organisasi karena ingin mencari pengalaman. Hal ini juga didapatkan pada penelitianPratiwi (2016). ${ }^{4}$ Hasil penelitian ini menunjukkan bahwa mahasiswa ingin mengaktualisasikan dirinya, mengembangkan bakatnya serta mencari pengalaman sebanyak-banyaknya dengan mengikuti organisasi. Hal ini sesuai dengan definisi organisasi mahasiswa yaitu suatu bentuk kegiatan yang berupaya untuk mengembangkan bakat, minat, ilmu, kegemaran, kesejahteraan mahasiswa dan merupakan bentuk tanggung jawab sosial kepada masyarakat. $^{7}$

Perbandingan prestasi belajar antara mahasiswa yang ikut dan tidak ikut organisasi didapatkan bahwa prestasi belajar mahasiswa yang ikut lebih baik dibandingkan dengan yang tidak ikut. Selain itu berdasarkan hasil analisis statistik didapatkan bahwa terdapat hubungan antara prestasi belajar dengan keikutsertaan dalam organisasi. Hal ini sesuai dengan pendapat Sukirman (2014), yang menyatakan bahwa manfaat mengikuti organisasi adalah membentuk 
sikap disiplin dan bertanggung jawab. ${ }^{8}$ Mahasiswa yang mengikuti organisasi cenderung untuk disiplin dalam membagi waktu antara belajar dan berorganisasi serta bertanggung jawab atas kewajibannya sebagai mahasiswa.

\begin{tabular}{rlr}
\multicolumn{2}{c}{ Perbandingan } & prestasi belajar \\
berdasarkan tingkat keaktifan dalam \\
berorganisasi didapatkan
\end{tabular}
yang tergolong tinggi keaktifannya memiliki prestasi belajar yang tergolong "sangat memuaskan" bila dibandingkan dengan kategori sangat rendah, rendah maupun sangat tinggi. Namun berdasarkan analisis statistik didapatkan bahwa tidak terdapat hubungan antara tingkat keaktifan berorganisasi dengan prestasi belajar. Hasil ini sesuai dengan penelitian Febriana (2013). ${ }^{3}$ Hal ini disebabkan karena adanya banyak faktor yang mempengaruhi prestasi belajar antara lain faktor internal dan eksternal.Faktor internal merupakan faktor yang berasal dari diri sendiri dan merupakan faktor yang paling dominan mempengaruhi prestasi belajar. Faktor internal tersebut antara lain keadaan fisik, kecerdasan, minat, motivasi dan manajemen waktu. Faktor eksternal adalah faktor yang berasal dari luar antara lain lingkungan keluarga, tempat tinggal dan kampus, fasilitas belajar serta ketersediaan teknologi. $^{9}$

\section{Kesimpulan}

1. Pada penelitian ini terdapat hubungan prestasi belajar antara mahasiswa yang mengikuti dan tidak mengikuti organisasi. Mahasiswa yang aktif dalam berorganisasi mempunyai prestasi belajar yang lebih baik daripada mahasiswa yang tidak ikut organisasi.

2. Pada penelitian ini tidak terdapat hubungan antara prestasi belajar dengan tingkat

keaktifan berorganisasi. Walaupun mahasiswa yang mempunyai tingkat keaktifan tinggi dalam berorganisasi mempunyai prestasi yang lebih baik, namun berdasarkan hasil analisis statistik terbukti tidak terdapat hubungan yang bermakna.

\section{Saran}

1. Memperbanyak responden penelitian sehingga mendapatkan gambaran yang lebih baik tentang hubungan antara prestasi belajar dengan keikutsertaan dan keaktifan mahasiswa dalam berorganisasi.

2. Melakukan analisis terhadap faktor - faktor internal dan eksternal sehingga dapat diketahui faktor - faktor yang mempengaruhi prestasi belajar mahasiswa.

\section{Referensi :}

1. Konsil Kedokteran Indonesia. 2012. Standar pendidikan profesi dokter Indonesia. Jakarta: KKI

2. Boelen, C. THE FIVE-STAR DOCTOR: An asset to health care reform? Diakses pada 23 Maret 2018. Tersedia dari: http: //www.who.int/hrh/en/HRDJ_1_1_02.

3. Febriana, B., Amriyatun, Winanti, L. \& Amelia, S. Hubungan Antara Keaktifan Organisasi Dengan Prestasi Belajar (Indeks Prestasi) Mahasiswa Fakultas IImu Keperawatan Universitas Indonesia. Prosiding Konferensi Nasional PPNI Jawa Tengah.2013.

4. Pratiwi, Siska S. 2016. Pengaruh Keaktifan Mahasiswa Dalam Organisasi Dan Motivasi Belajar Terhadap Prestasi Belajar Mahasiswa Fakultas Ekonomi Universitas Negeri Yogyakarta. Skripsi : Universitas Negeri Yogyakarta.

5. Nanda, Seftia S. 2017. Hubungan Kebiasaan Belajar Dan Keaktifan Berorganisasi Terhadap Prestasi Belajar Mahasiswa Tahun Ketiga

Fakultas Kedokteran Universitas Lampung.Skripsi : Universitas Lampung.

6. Mardapi, D. 2008. Teknik Penyusunan Instrumen Tes dan Nontes. Yogyakarta : Mitra Cendekia.

7. Universitas Lampung. 2013. Lembaga mahasiswa. Diakses pada 24 Maret 2018.

Tersedia dari: http://www.unila.ac.id/lembaga-mahasiswa/.

8. Sukirman, S. 2004. Tuntunan belajar di perguruan tinggi. Jakarta: Pelangi Cendekia.

9. Djamarah, S.B. 2011. Rahasia sukses belajar. Jakarta: Rineka Cipta. 